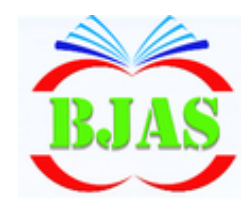

Available online at http://www.bajas.edu.iq

https://doi.org/10.37077/25200860.2019.284

College of Agriculture, University of Basrah

ISSN $1814-5868$

Basrah J. Agric. Sci., 32(Spec. Issue 2): 373-388, 2019
Basrah Journal of Agricultural Sciences

E-ISSN: 2520-0860

\title{
A Field Study of Soil Pulverization Energy by using Different Moldboards Types Under Various Operating Condition
}

\author{
Ali A. Alwan \\ Department of Agricultural Machines and Equipment, College of Agriculture, University of \\ Basrah, Iraq \\ *Corresponding author e-mail: ali-alwan@uobasrah.edu.iq
}

Received 20 April 2019; Accepted 18 June 2019; Available online 22 October 2019

\begin{abstract}
A field experiment was conducted in the experiment field of Agricultural College, Basrah University, to study the effect of three types of moldboards i.e. helical, general purpose and digger moldboard, three tillage depths $(15,20$ and 25 $\mathrm{cm}$ ) and three forward speeds $\left(4.37,6.11\right.$ and $\left.7.03 \mathrm{~km} \mathrm{~h}^{-1}\right)$ on the draft force (DF), soil pulverization index (SPI), the specific energy (SE), the energy equivalent (EQE), and soil pulverization efficiency (SPE). Split-split plot with complete randomized block design with three replications were used in this study, and Least significant differences (LSD) was used to compare the means of treatments at 0.05 levels. The results showed there was a significant effect for moldboard types, plowing depths, plowing speeds and the interaction on all studied parameters. Whereas the digger moldboard type achieved the lower values of DF and SPI compared with the general purpose and helical moldboard types by percentage of 12.13 and $19.49 \%$ respectively and 16.37 and $50.61 \%$ respectively. However, the digger moldboard gave the highest value of SPE of $80 \%$. The results Also, indicated to that the plowing depth and plowing speed had a significant effect on studied parameters when increasing the plowing depth by percentage $67 \%$ the DF and SPI increased by $137.27 \%$ and $30.46 \%$, while the SE, the EQE and SPE reduced by $18.19,17.80$ and $2.70 \%$ respectively. However, increasing the plowing speed by a percentage of $61 \%$, the DF, SE, EQE, and SPE increased by $25.98,45.11,8.18$ and $35.59 \%$ respectively, while the SPI decreased by $29.15 \%$.
\end{abstract}

Key words: Moldboards types, Plowing depth, Plowing speed, SPI and Soil pulverization efficiency.

\section{Introduction}

The moldboard plow is one of the most important primary soil preparation equipment. moldboard plow can achieve all plowing goals through cut the soil and overturning it, which helps to pulverize the soil, thereby provide the suitable cradle for seed germination and growth, (Abdallah et al., 2016). The preparation of soil to agriculture and the provision of a suitable seedbed requires more than $60 \%$ of the energy consumed in all agricultural operations (Jacobs \& Harrol, 1983). Therefore, part of the energy that spent in tillage operations can be reduced through the use of different designs of shares or moldboards because of their direct effect in the process of cutting the soil and its overturn. The 


\section{Alwan / Basrah J. Agric. Sci., 32(Spec. Issue 2): 373-388, 2019}

requirements of the draft force of the plow are based on the geometric design of the moldboards (Maky \& Desir, 1984). Draft force is an essential indicator for evaluating plows performance. (Nassir, 2016) found that the draft force of the moldboard plow increases linearly with the increase width of the moldboard, Aday \& Al-Edan (2004) noted that the draft force of the moldboard plow with a serrated moldboard - type reduced the draft force by 17.5 and $22.5 \%$, compared with the deep digger moldboard plow type in moist and fragile soil respectively. The depth of tillage and forward speed had an effect on the energy requirements of the plow. Al- Hadithi (2015) confirmed that the draft force increased from 9 to $13.5 \mathrm{kN}$ when the plowing depth is increased from 10 to $20 \mathrm{~cm}$ for the normal plow. while using the modified moldboard plow by added vertical fins led to increasing the draft force from 10.8 to $31.5 \mathrm{kN}$. Also Nassir et al. (2016) found that the draft force increased significantly with the increase of the speed of the plowing. The tillage practices of all types of moldboard plows aim to break up the soil blocks. This will help in the preparation of a good seedbed facilitated to germination the seeds thereby spreading the roots in the soil to take sufficient water, air and nutrients so it is important to study the soil pulverization index (SPI) (Mean Weight Diameter) which are a standard for the degree of soil pulverization. In study conducted by Nassir (2018) on three different body types of moldboard plow he found that generalpurpose plow had maximum value of the soil pulverizing percentage was $60 \%$, while semi digger plow and helical plow had minimum values of the soil pulverizing percentage of 53 and $40 \%$ respectively. Nassir (2017) found that the increase in forward speed from 0.8 to 1.62 $\mathrm{m} \mathrm{sec}^{-1}$ decreased the soil pulverization index (SPI) from 88.02 to $61.83 \mathrm{~mm}$ while the soil pulverization index increased from 79.34 to $81.5 \mathrm{~mm}$ when the plowing depth increased from 22 to $23 \mathrm{~cm}$. The reduction of the soil pulverization index (SPI) values should be performed by the lowest energy requirements and this achieved by increasing the plow efficiency on soil pulverization. The field energy (specific energy) is the energy used in the field to overcome the forces of cohesion and friction among the soil blocks in order to break up the soil and its fragmentation. Aday \& Al-Edan (2004) found that the specific energy of the plow was reduced with increasing depth due to the increase in the size of the plowed soil more than the increase in the energy requirements, while the specific energy increased with the increase of the plowing speed due to increase energy requirements with a decrease in the distribution area. The field energy (specific energy) is the energy required by plowing implement to cutting, breaking down soil, and fragmentation the soil. Nassir (2016) found that the modified moldboard plow had lower specific energy compared to deep digger moldboard plow type by percentage of $25.36 \%$. Khader (2008) noted that the specific energy of moldboard plow increased with increasing plowing speed, it increased from 79.51 to $108.02 \mathrm{~kJ} . \mathrm{m}^{-3}$, when the plowing speed increased from 0.89 to 1.92 $\mathrm{m} \mathrm{sec}^{-1}$. The equivalent energy is the energy required to fragmentation the soil only. It had been estimated in the laboratory (Nassir, 2014). The energy efficiency of the plow is increases with the convergence of the specific energy (field energy) and the equivalent energy (laboratory). The energy efficiency of the plow is equal to the equivalent energy divided by the specific energy. The closer the two energies, the plow becomes more efficient (Nassir et al., 2016). The aim of this study to compare among three different bodies of the moldboard plow in term the energy 
pulverization requirements including the soil pulverization index (SPI), the specific energy, the energy equivalent, and energy pulverization efficiency at different plowing depths and plowing speeds in clay loamy soil.

\section{Materials \& Methods}

\section{Description of moldboard plows:}

Three types of moldboard plow were utilized i.e. general-purpose moldboard, semi-helical moldboard, and digger moldboard. Specification of three moldboard types are illustrated in table (1).

\section{Tractors used}

Two different tractors were used in this study. The specifications were demonstrated in table (2).

\section{Measure the draft force:}

Load cell $(250 \mathrm{kN})$ was used to evaluate the draft force of the plow. The load cell was attached between the Massey-Ferguson 440 axtra tractor and the Massey-Ferguson 285s tractor loaded of plow by a flexible cable. The gearbox of Massey-Ferguson 285s tractor was putted in idle gear position. This tractor onlycontrols on plowing depth by the hydraulic system in order to keep plowing depth at the required depth. Whereas draft force was recorded for all the plowing depth and plowing speed by a portable computer connected with load cell by USB. In the same way, the rolling resistance is measured but the plow outside of the soil surface and is portable on the tractor (Massey-Ferguson 285s), and the draft force was calculated from the following equation (Aday \& Al-Edan, 2004):

$$
F=F_{\text {total }}-R
$$

Where: : Draft force $(\mathrm{kN}) ; F_{\text {total }}$ : Total draft force $(\mathrm{kN}) ; R$ : Rolling resistance $(\mathrm{kN})$.

\section{Soil pulverization index}

Random samples were taken from the experiment field after the plowing operating for all treatments. After sampling from the field. The samples were passed the sieving device shown in Fig. (2). The sieves had meshed of (100-70, 70-50, 50-30, 30- 20, 20$5.0, \quad 5.0-2.0, \quad 2.0-1.7 \mathrm{~mm})$ where the pulverization index of soil was calculated from the following equation (2), according to the method mentioned in Hillel (1980).

$P I=\frac{\sum W i * \bar{d} i}{W_{\text {total }}}$

Where: PI: Pulverization index; Wi $=$ The weight of the clods of soil found between two sieves di and di+1; $\mathrm{W}_{\text {total }}=$ The weight of the total mass; $\mathrm{n}=$ The number of sieves; In Eq. 2, di was calculated using the following equation: $\bar{d} \iota=\frac{1}{2}\left(d_{i}+d_{i+1}\right)$

Table (1): Specification of three types bodies of moldboard.

\begin{tabular}{cccccc}
\hline Moldboard type & $\begin{array}{c}\theta_{\mathrm{s}} \\
(\mathrm{deg})\end{array}$ & $\begin{array}{c}\theta_{\mathrm{i}} \\
(\mathrm{deg})\end{array}$ & $\begin{array}{c}\mathrm{Ws}_{\mathrm{S}} \\
(\mathrm{mm})\end{array}$ & $\begin{array}{c}\mathrm{LL}_{\mathrm{L}} \\
(\mathrm{mm})\end{array}$ & $\begin{array}{c}\mathrm{L}_{0} \\
(\mathrm{~mm})\end{array}$ \\
\hline General-purpose & 35 & 27 & 275 & 180 & 800 \\
\hline Helical & 37 & 30 & 290 & 250 & 1105 \\
\hline Digger & 33 & 28 & 260 & 150 & 900 \\
\hline
\end{tabular}

$\mathrm{L}_{\mathrm{L}}=$ landslide length. $L o=$ overall length of bottom $\mathrm{W}_{\mathrm{S}}=$ share culling width perpendicular to the direction of travel. $\theta_{\mathrm{i}}=$ share wing angle. $\theta_{\mathrm{s}}=1+$ ateral directional moldboard tail angle. 


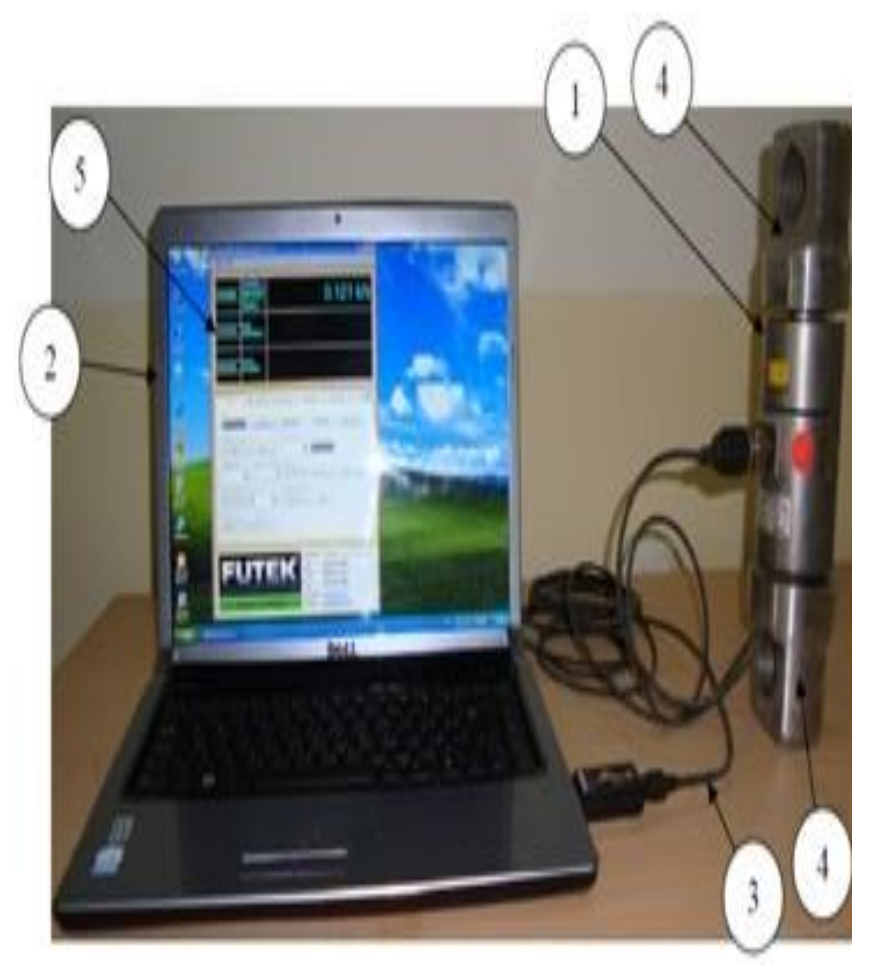

Fig. (1): Measurement device of draft force

Abbreviation: 1-Load cell. 2- laptop. 3- USB connection. 4- Two rings to fixation of the load cell. 5program recorded and saved data of draft force.

\section{Energy required to soil pulverization:}

Samples of the experiment field were collected randomly for each plowing depths $(15,20$, and $25 \mathrm{~cm})$ and forward speeds $(0.46,0.73$ and 1.18 $\left.\mathrm{m} \cdot \mathrm{sec}^{-1}\right)$. The blocks of soil left to dry in the lab for two weeks. Each soil block was weighted after that soil blocks were dropped from an altitude of $80 \mathrm{~cm}$ on hard ground many times.
The pulverization index (mentioned previously) was estimated for each time had been soil block dropped, until the soil blocks become the small size and unbreaking. The energy required to soil pulverization for each dropping process of the

\section{Soil properties and soil texture}

It is summarized in table (3). The methods of measurements mounted in Black et al. (1993).

\section{Energy required to soil pulverization}

Samples of the experiment field were collected randomly for each plowing depths $(15,20$, and $25 \mathrm{~cm})$ and forward speeds $(0.46,0.73$ and 1.18 m.sec-1). The blocks of soil left to dry in the lab for two weeks. Each soil block was weighted after that, soil blocks.

Soil block was calculated from the following equation (Aday et al., 2004):

$E S P=(m * g * z) * n$

were dropped from an altitude of $80 \mathrm{~cm}$ on hard ground many times. The pulverization index (mentioned previously) was estimated Where: ESP: Potential energy $(\mathrm{kJ}) ; m$ : mass of soil blocks $(\mathrm{kg}) ; g$ : gravitational force $\left(\mathrm{m} . \mathrm{sec}^{-2}\right) ; z$ : dropping height of soil block (m); $n$ : number times dropping of soil block.

Table (2): Tractor specifications.

\begin{tabular}{ccc}
\hline Parameters & Massey- Ferguson 440 xtra & Massey-Ferguson 285s \\
\hline Max Hp (kW) power & $82(61.1)$ & $77(65.6)$ \\
\hline Engine speed (rpm) & 2200 & 2000 \\
\hline Engine type & Perkins (diesel) & Perkins (diesel) \\
\hline Engine capacity (litter) & 4.40 & 4.06 \\
\hline No. of cylinder & 4 & 4 \\
\hline Compression ratio & $18.5: 1$ & $17.5: 1$ \\
\hline Thrust generation & MFWD & $2 \mathrm{WD}$ \\
\hline
\end{tabular}


Alwan / Basrah J. Agric. Sci., 32(Spec. Issue 2): 373-388, 2019

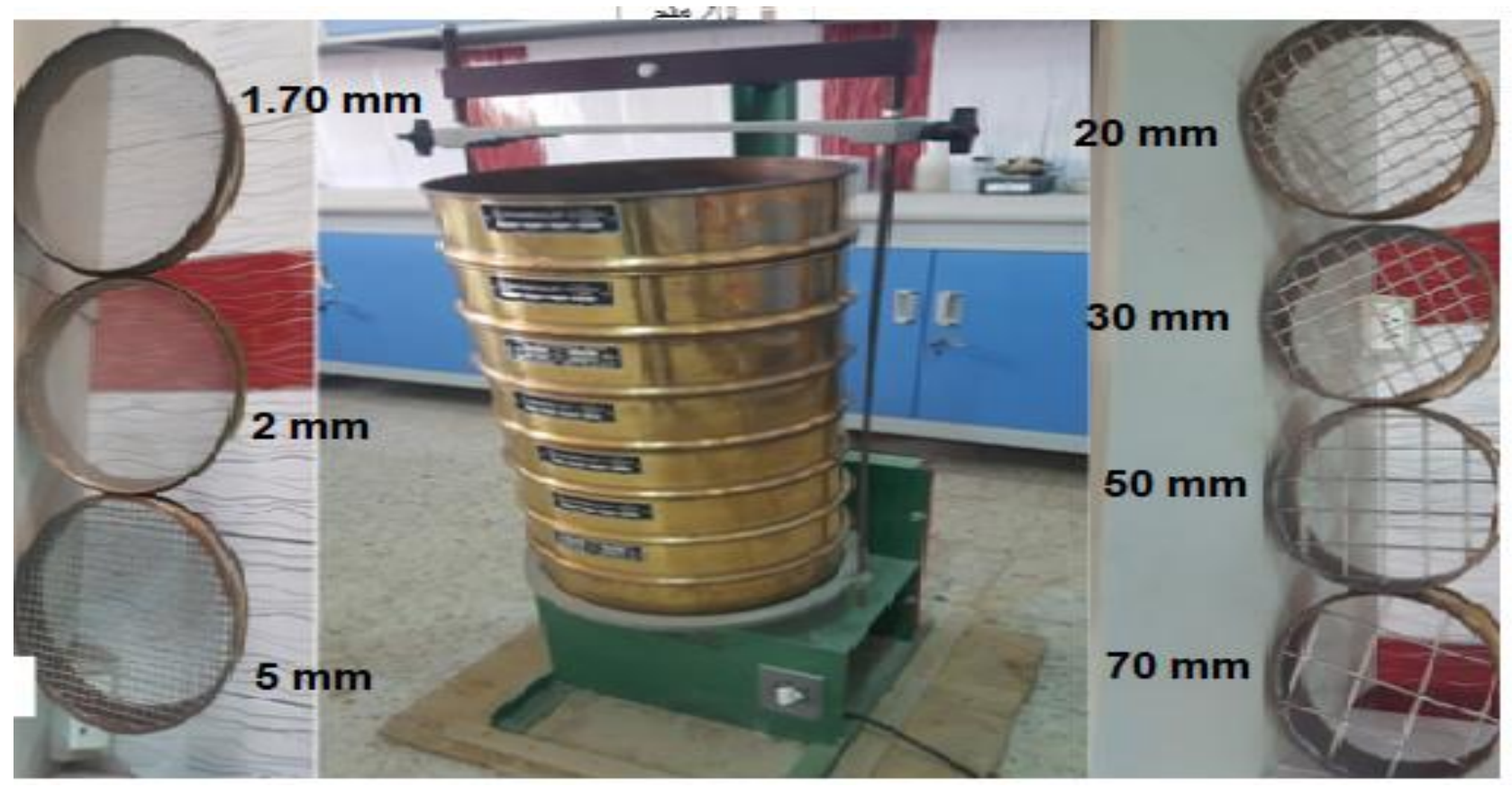

Fig. (2): The sieve device and sieves used.

\section{Equivalent energy}

Its estimated from fig. (3), which consider Logarithmic relationship between soil pulverization energy and pulverization index (PI). Where equivalent energy was estimated by dropping the pulverization Index (PI) which was determined in the field on the relationship between pulverization Index (PI) (Y-axis) and the energy required to soil Pulverization (X-axis). To obtain the equivalent energy values were multiplied the mean of soil bulk density values by the energy of pulverization for each treatment. Equivalent energy calculated by the following equation (Black et al., 1993).

$$
E q E=(m * g * z) * \rho b
$$

Where:

$E q E$ : Equivalent energy $\left(\mathrm{kJ} \mathrm{m}^{-3}\right)$. $\rho b$ : bulk density $\left(\mathrm{Mg} \mathrm{m}^{-3}\right)$.

\section{The specific energy}

It is calculated as follows equation (Aday, 1997)

$$
S p E=\frac{F}{A} * \frac{m}{m} .
$$

Where:

$S p E=$ specific energy $\left(\mathrm{kJ} \cdot \mathrm{m}^{-3}\right)$.

F: draft force $(\mathrm{kN})$.

A: cross-section width of the plowed soil by the plow $\left(\mathrm{m}^{2}\right)$.

$m$ : one meter of soil plowed along the operating path $(\mathrm{m})$.

\section{The pulverization efficiency}

It is calculated as follows equation. (Aday (3))

$$
\eta=\frac{E q E}{S p E} * 100
$$

Where: ${ }^{\eta}=$ Pulverization energy efficiency $(\%)$ 
Alwan / Basrah J. Agric. Sci., 32(Spec. Issue 2): 373-388, 2019

Table (3): Soil properties and soil texture.

\begin{tabular}{cccc}
\hline $\begin{array}{c}\text { Plowing depth } \\
(\mathrm{cm})\end{array}$ & $\begin{array}{c}\text { Moisture content } \\
(\%)\end{array}$ & $\begin{array}{c}\text { Bulk density } \\
\left(\mathrm{g} . \mathrm{cm}^{-3}\right)\end{array}$ & $\begin{array}{c}\text { Soil penetration } \\
\text { resistance } \\
\left(\mathrm{kN} . \mathrm{m}^{-2}\right)\end{array}$ \\
\hline $10-0$ & 10.30 & 1.25 & 1545.32 \\
\hline $15-10$ & 15.50 & 1.30 & 1989.86 \\
\hline $25-15$ & 18.20 & 1.48 & 2502.86 \\
\hline Soil texture & $\begin{array}{c}\text { Sand } \\
\left(\mathrm{gm}_{\mathrm{kg}} \mathrm{kg}^{-1}\right)\end{array}$ & $\begin{array}{c}\mathrm{Silt} \\
\left(\mathrm{gm}_{\mathrm{kg}}-1\right)\end{array}$ & $\begin{array}{c}\text { clay } \\
\left(\mathrm{gm}_{\mathrm{kg}} \mathrm{kg}^{-1}\right)\end{array}$ \\
\hline Silty loam & 276.73 & 552.45 & 170.82 \\
\hline
\end{tabular}

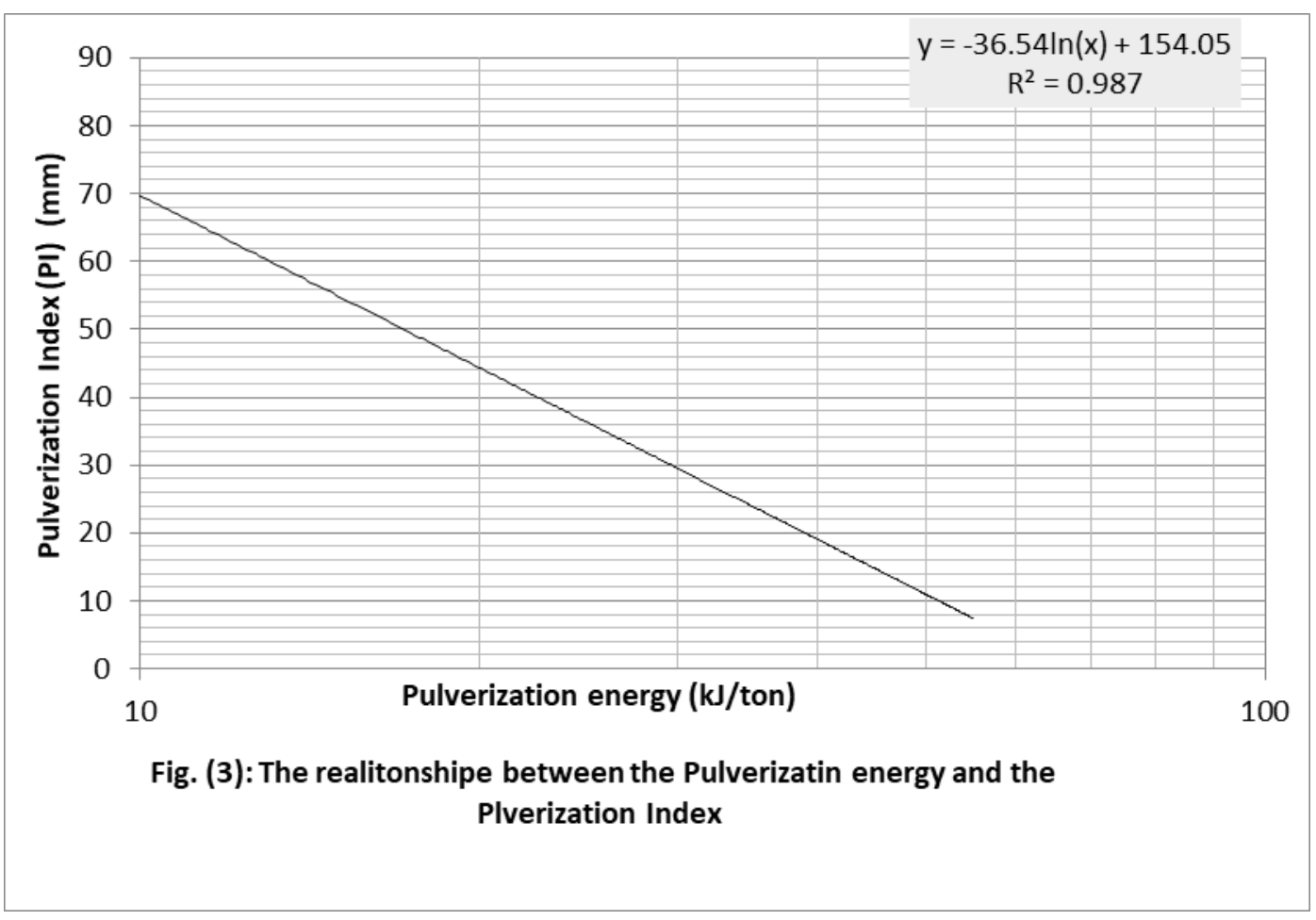




\section{Result \& Discussion}

\section{Draft force:}

Table (4) explained that there was a significant effect of moldboard types on draft force. The results showed that the plowing by digger moldboard reduced the draft force required to pull the plow by percentage of $0.12 \%$ and $0.19 \%$ respectively, compared to the general-purpose and helical moldboard. The reason is that the variation in the design of the moldboard. The big geometric dimensions of the helical moldboard recorded a higher draft force of $13.80 \mathrm{kN}$. This is in accordance with the results notified by Naderloo et al. (2009).

The plowing depth had significant effect in draft force (table 4). The results showed that increasing the plowing depth where increasing plowing depth from 15 to $20 \mathrm{~cm}$ increased draft force from 7.38 to $12.68 \mathrm{kN}$ by increasing percentage of $72 \%$. Furthermore, increasing the plowing depth to $25 \mathrm{~cm}$ recorded the highest the draft force value of $17.51 \mathrm{kN}$ by increasing percentage of $38 \%$. This was because of the increase in the weight of the soil which needs additional draft force to overcome the considerable weight which results from increasing the plowing depth. This results agree with the results reported by Nassir (2016).

The draft force significantly affects in plowing speed (table 4). Whereas increasing the plowing speed from 4.37 to $6.11 \mathrm{~km} \mathrm{~h}^{-1} \mathrm{draft}$ force increased from 11.16 to $12.34 \mathrm{kN}$ also, increasing plowing speed from 6.11 to $7.03 \mathrm{~km} \mathrm{~h}^{-1}$ draft force increased from 12.34 to $14.06 \mathrm{kN}$. This is due to the increasing acceleration of the soil blocks and gives it a kinetic energy to overcome the strength of cohesion between soil particles and the strength of friction between the blocks of soil, which causes an increase in the draft force. Similar findings reported by Naderloo et al. (2009) and Jasim \& Mankhi (2012).

Table (4): Effect of moldboard type, plowing depth, and forward speed in draft force.

\begin{tabular}{cccc}
\hline Forward speed & $4.37 \mathrm{~km} \mathrm{~h}^{-1}$ & $5.51 \mathrm{~km} \mathrm{~h}^{-1}$ & $6.76 \mathrm{~km} \mathrm{~h}^{-1}$ \\
\hline Moldboard types & 11.16 & 12.34 & 14.06 \\
\hline Helical & General-purpose & Digger \\
\hline Plowing depth & 13.80 & 12.67 & 11.11 \\
\hline & $15 \mathrm{~cm}$ & $20 \mathrm{~cm}$ & $25 \mathrm{~cm}$ \\
\hline L.S.D.(0.05) & 7.38 & 12.68 & 17.51 \\
\hline
\end{tabular}


The results of interaction among plowing types, plowing depth and plowing speed were shown in table (5). The results of interaction among moldboard type, plowing depth, and speed had significant effect on draft force. The helical moldboard type recorded the highest value of draft force $(20.67 \mathrm{kN})$ when using its in deep plowing of $25 \mathrm{~cm}$ and high plowing speed of $7.03 \mathrm{~km} \cdot \mathrm{h}^{-1}$. While the digger moldboard types recorded the lowest value of draft force $(5.49 \mathrm{kN})$ when using its in shallow depth of $15 \mathrm{~cm}$ and low plowing speed of 4.37 $\mathrm{km} \cdot \mathrm{h}^{-1}$. Similar findings reported by Taniguchi et al. (1999), Sahu \& Raheman (2006) and AlHashimy (2012).

Table (5): Effect of interaction among moldboard type, plowing depth, and forward speed in draft force.

\begin{tabular}{|c|c|c|c|c|c|}
\hline & \multicolumn{5}{|c|}{ Forward speed $\left(\mathrm{km} \mathrm{h}^{-1}\right)$} \\
\hline & Depth & 4.37 & 5.51 & 6.76 & Means \\
\hline \multirow{4}{*}{ 苞 } & 15 & 6.06 & 9.06 & 10.23 & 8.45 \\
\hline & 20 & 12.48 & 13.47 & 16.02 & 13.99 \\
\hline & 25 & 17.61 & 18.63 & 20.67 & 18.97 \\
\hline & Means & 12.05 & 13.72 & 15.64 & 13.80 \\
\hline \multirow{4}{*}{ 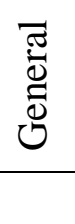 } & 15 & 5.85 & 7.23 & 9.00 & 7.36 \\
\hline & 20 & 11.67 & 12.03 & 15.03 & 12.91 \\
\hline & 25 & 17.31 & 17.55 & 18.33 & 17.73 \\
\hline & Means & 11.61 & 12.27 & 14.12 & 12.67 \\
\hline \multirow{5}{*}{ 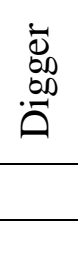 } & 15 & 5.49 & 6.00 & 7.5 & 6.33 \\
\hline & 20 & 9.45 & 11.31 & 12.69 & 11.15 \\
\hline & 25 & 14.55 & 15.81 & 17.1 & 15.82 \\
\hline & Means & 9.83 & 11.04 & 12.43 & 11.1 \\
\hline & L.S.D.(0.05) & \multicolumn{4}{|c|}{ Type*Depth* Speed $=0.804$} \\
\hline
\end{tabular}

\section{Soil pulverization index (SPI)}

Soil pulverization index was significantly $(p \leq 0.05)$ affected by moldboard types. The results in table (6), referred that helical moldboard type recorded the highest soil pulverization index values of $25 \mathrm{~mm}$ compared with general purpose and digger which recorded 15.02 and $12.56 \mathrm{~mm}$ respectively. The results in table (6), referred that helical moldboard type recorded the highest soil pulverization index values of $25 \mathrm{~mm}$ compared with general purpose and digger which recorded 15.02 and $12.56 \mathrm{~mm}$, respectively.
These results could be attributed to increasing soil volume which was cut and overturned by helical moldboard type due to its a great edge width of the helical moldboard, leading to increasing the soil pulverization index, while the digger moldboard plow had small edge width and this allowed to pulverization of soil considerably greater than overturning soil blocks. Similar results were also reported by Nassir (2018).

Plowing depth had a significant effect $(\mathrm{p} \leq 0.05)$ in soil pulverization index (table, 6$)$. 
When increasing the plowing depth from 15 to 20 and $25 \mathrm{~cm}$ increased the soil pulverization index from $14.88,18.73$ and $21.44 \mathrm{~mm}$ respectively, by increasing percentage of $43.8 \%$ and $16 \%$. This increasing of soil pulverization index could be attributed to the increasing volume of the plowed soil with increasing depth where the soil has a high strength due to the increased strength of soil adhesion and its cohesion thus making soil pulverization reduced his is in conformity with Rashidi \& Keshavarzpour (2007) and Muhsin (2017b).

Plowing speed had a significant effect on soil pulverization index (table 6). Whereas when increasing plowing speed from 4.37 to $6.11 \mathrm{~km}$ $\mathrm{h}^{-1}$ the soil pulverization index decreased from 21.23 to $17.74 \mathrm{~mm}$ by percentage $16.44 \%$. However, Increasing plowing speed from 4.37 to $7.03 \mathrm{~km}$. $\mathrm{h}^{-1}$. The results showed that the pulverization index (SPI) decreased with increasing the plowing speed. This could be attributed to an increase in acceleration of the soil blocks and collision it each to other led to break up the soil blocks to small sizes which decrease the soil pulverization index (SPI) thereby increasing the soil pulverization. These results agree with Aday (1997), Nassir (2017) and Muhsin (2017a).

Table (6): Effect of interaction among moldboard type, plowing depth, and forward speed in soil pulverization index

\begin{tabular}{|c|c|c|c|c|c|}
\hline & \multicolumn{5}{|c|}{ Forward speed $\left(\mathrm{km} \mathrm{h}^{-1}\right)$} \\
\hline & Depth & 4.37 & 5.51 & 6.76 & Means \\
\hline \multirow{4}{*}{ 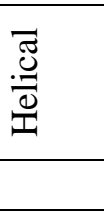 } & 15 & 24.66 & 21.00 & 15.23 & 20.30 \\
\hline & 20 & 30.23 & 24.80 & 20.90 & 25.31 \\
\hline & 25 & 35.23 & 29.66 & 27.13 & 30.67 \\
\hline & Means & 30.04 & 25.15 & 21.09 & 25.43 \\
\hline \multirow{4}{*}{ 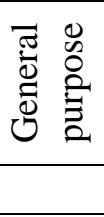 } & 15 & 15.90 & 13.00 & 10.16 & 13.02 \\
\hline & 20 & 17.63 & 14.26 & 12.66 & 14.85 \\
\hline & 25 & 20.50 & 15.27 & 15.76 & 17.18 \\
\hline & Means & 18.01 & 14.18 & 12.86 & 15.02 \\
\hline \multirow{4}{*}{ 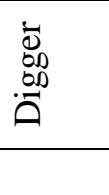 } & 15 & 13.12 & 11.68 & 9.16 & 11.32 \\
\hline & 20 & 15.16 & 12.89 & 11.05 & 13.03 \\
\hline & 25 & 18.63 & 17.08 & 13.30 & 16.34 \\
\hline & Means & 15.64 & 13.88 & 11.17 & 13.56 \\
\hline
\end{tabular}

The interaction among moldboard type, depth, and speed had significant effect $(\mathrm{p} \leq 0.05)$ in soil pulverization Index (table 7). The helical moldboard type operating at plowing depth of $25 \mathrm{~cm}$ and low speed of $4.37 \mathrm{~km} . \mathrm{h}^{-1}$ achieved the highest value of soil pulverization index (35.23 $\mathrm{mm}$ ), while digger moldboard type achieved the lowest value of soil pulverization index $(9.16 \mathrm{~mm})$. 
Alwan / Basrah J. Agric. Sci., 32(Spec. Issue 2): 373-388, 2019

Table (7): Effect of moldboard type, plowing depth, and forward speed in pulverization index.

\begin{tabular}{cccc}
\hline Forward speed & $\begin{array}{c}4.37 \\
\mathrm{~km} \mathrm{~h}^{-1}\end{array}$ & $\begin{array}{c}5.51 \\
\mathrm{~km} \mathrm{~h}^{-1}\end{array}$ & $\begin{array}{c}6.76 \\
\mathrm{~km} \mathrm{~h}^{-1}\end{array}$ \\
\hline & 21.23 & 17.74 & 15.04 \\
\hline Moldboard types & Helical & General-purpose & Digger \\
\hline & 25.43 & 15.05 & 12.56 \\
\hline Plowing depth & $15 \mathrm{~cm}$ & $20 \mathrm{~cm}$ & $25 \mathrm{~cm}$ \\
\hline L.S.D.(0.05) & 14.88 & 17.73 & 21.40 \\
\hline & Type $=0.883$ & Depth $=1.073 \quad$ Speed $=0.980$ &
\end{tabular}

\section{Equivalent energy (EQE)}

The effect of moldboard types on equivalent energy was shown in table (8). Digger moldboard type resulted in significant $(\mathrm{p} \leq 0.05)$ higher values of equivalent energy than helical moldboard type and general purpose moldboard type by percentage of $18.18 \%$ and $56.49 \%$ respectively. This attributed to depending the equivalent energy on values of soil pulverization index which estimated from fig (3), where the equivalent energy increased with reducing the soil pulverization index. The effect of plowing depth had a significant effect $(\mathrm{p} \leq 0.05)$ on equivalent energy it as shown in table (8). Whereas the plowing depth of $15 \mathrm{~cm}$ recorded the highest value of equivalent energy was $135.91 \mathrm{~kJ}$

$\mathrm{m}^{-3}$ and more than plowing depths of 20 and 25 $\mathrm{cm}$ by an amounted of 13.01 and $24.20 \mathrm{~kJ} \mathrm{~m}^{-3}$ respectively. This was because of the equivalent energy which determined experimentally depending on the soil pulverization index (SPI). where the equivalent energy had been related by an inverted relationship with pulverization index (SPI) as is illustrated in (Fig. 3). Where low value pulverization index (SPI) need high equivalent energy thereby increasing the equivalent energy when reduction plowing depth. The effects of plowing depth on the equivalent energy are similar to the results obtained by Nassir (2017) and equivalent energy affected significantly $(\mathrm{p}<0.05)$ by plowing speed (table 8$)$. When increasing the plowing speed from 4.37 to 7.03 $\mathrm{km} \mathrm{h}^{-1}$ the equivalent energy increased from 97.71 to $141.79 \mathrm{~kJ} \mathrm{~m}^{-3}(45.11 \%)$.

Table (8): Effect of moldboard type, plowing depth, and forward speed in equivalent energy.

\begin{tabular}{llll}
\hline Moldboard types & Helical & General-purpose & Digger \\
\hline & 111.71 & 122.90 & 168.4 \\
\hline Plowing depth & $15 \mathrm{~cm}$ & $20 \mathrm{~cm}$ & $25 \mathrm{~cm}$ \\
\hline & 125.91 & 126.17 & 149.12 \\
\hline Forward speed & $4.37 \mathrm{~km} \mathrm{~h}^{-1}$ & $5.51 \mathrm{~km} \mathrm{~h}^{-1}$ & $6.76 \mathrm{~km} \mathrm{~h}^{-1}$ \\
\hline & 97.71 & 131.07 & 141.79 \\
\hline
\end{tabular}

\begin{tabular}{llll}
\hline L.S.D. $(0.05)$ & Type $=3.21$ & Depth $=4.41$ & Speed $=3.87$
\end{tabular}

The interaction among moldboard type, effect $(\mathrm{p} \leq 0.05)$ in equivalent energy (table 9$)$. plowing depth and speed had effect significant The maximum value of equivalent energy was 
$188.16 \mathrm{~kJ}^{-3} \mathrm{~m}^{-3}$ when using the digger moldboard type at plowing depth of $20 \mathrm{~cm}$ and plowing speed of $7.03 \mathrm{~km} . \mathrm{h}^{-1}$ while the minimum value of equivalent energy was $55.68 \mathrm{~kJ} \mathrm{~m}^{-3}$ when using the digger moldboard type at plowing depth of $25 \mathrm{~cm}$ and plowing speed of 4.37 $\mathrm{km} \mathrm{h}^{-1}$.

Table (9): Effect of interaction among moldboard type, plowing depth, and forward speed in equivalent energy.

\begin{tabular}{|c|c|c|c|c|c|}
\hline & \multicolumn{5}{|c|}{ Forward speed $\left(\mathrm{km} \mathrm{h}^{-1}\right)$} \\
\hline & Depth & 4.37 & 5.51 & 6.76 & Means \\
\hline \multirow{4}{*}{ 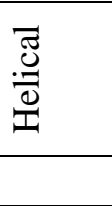 } & 15 & 68.76 & 115.80 & 126.72 & 103.76 \\
\hline & 20 & 60.45 & 122.61 & 82.98 & 88.68 \\
\hline & 25 & 55.68 & 96.51 & 128.07 & 93.42 \\
\hline & Means & 61.63 & 111.64 & 112.59 & 95.29 \\
\hline \multirow{4}{*}{ 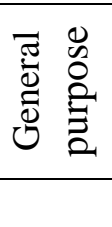 } & 15 & 105.66 & 135.87 & 156.24 & 132.59 \\
\hline & 20 & 101.34 & 141.69 & 164.25 & 135.76 \\
\hline & 25 & 86.88 & 115.86 & 127.77 & 110.17 \\
\hline & Means & 97.96 & 131.14 & 149.42 & 126.17 \\
\hline \multirow{5}{*}{$\begin{array}{l}\bar{\Delta} \\
.00 \\
.00 \\
\overline{0}\end{array}$} & 15 & 163.11 & 172.68 & 178.35 & 171.38 \\
\hline & 20 & 106.80 & 137.85 & 188.16 & 144.27 \\
\hline & 25 & 130.74 & 140.79 & 123.60 & 131.71 \\
\hline & Means & 133.55 & 150.44 & 163.37 & 149.12 \\
\hline & L.S.D.(0.05) & \multicolumn{4}{|c|}{ Type*Depth* Speed $=6.24$} \\
\hline
\end{tabular}

\section{Specific energy (SE)}

Helical mouldboard had the lowest value of specific energy compared with moldboard types of the digger and general purpose by an amount of 10.77 and $11.84 \mathrm{~kJ}^{-3} \mathrm{~m}^{-3}$ respectively (table 10). This was because of the increasing the distributed area more than increasing in draft force for helical moldboard, therefore recorded the lowest value of specific energy $(157.27 \mathrm{~kJ}$ $\mathrm{m}^{-3}$ ) according to equation (6). This is in accordance with Kader (2008) and Arvidsson et al. (2004). There were no significant differences between the values of specific energy for digger moldboard type and general purpose moldboard type. The effect of plowing depth had a significant effect $(\mathrm{p}<0.05)$ on specific energy it as shown in table (10). Whereas the plowing depth of $15 \mathrm{~cm}$ recorded the highest value of specific energy $\left(182.76 \mathrm{~kJ} \mathrm{~m}^{-3}\right)$. The lowest value of specific energy recorded by plowing

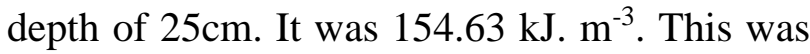
because of increasing the soil distribution area greater than increasing in draft force when increasing the plowing depth. are similar to the results obtained by Nassir (2017) and Aday \& Al-Edan (2004). It can be observed from table (10), there were no significant differences between plowing speed of 6.11 and $7.03 \mathrm{~km} . \mathrm{h}^{-1}$ on specific energy. The increasing the specific energy with increasing plowing speed could be attributed to increasing the draft force requirements considerably with increasing the plowing speed. These results agree with the results conducted by Nassir (2014). 
Alwan / Basrah J. Agric. Sci., 32(Spec. Issue 2): 373-388, 2019

Table (10): Effect of moldboard type, plowing depth, and forward speed in specific en

\begin{tabular}{cccc}
\hline Forward speed & $4.37 \mathrm{~km} \mathrm{~h}^{-1}$ & $5.51 \mathrm{~km} \mathrm{~h}^{-1}$ & $6.76 \mathrm{~km} \mathrm{~h}^{-1}$ \\
\hline & 161.77 & 174.09 & 175.01 \\
\hline Moldboard types & Helical & General-purpose & Digger \\
\hline & 157.27 & 169.11 & 168.4 \\
\hline Plowing depth & $15 \mathrm{~cm}$ & $20 \mathrm{~cm}$ & $25 \mathrm{~cm}$ \\
\hline & 154.63 & 175.03 & 182.76 \\
\hline L.S.D.(0.05) & Type $=3.74$ & Depth $=4.42$ & Speed $=3.88$ \\
\hline
\end{tabular}

The interaction among moldboard type, plowing depth and speed had effect significant in specific energy (table 11). The Digger moldboard type operating at plowing depth of $15 \mathrm{~cm}$ and low speed of $4.37 \mathrm{~km} \mathrm{~h}^{-1}$ give the highest value of specific energy $\left(210.99 \mathrm{~kJ} . \mathrm{m}^{-}\right.$
${ }^{3}$ ), while Helical moldboard achieved the lowest value of specific energy $\left(114.30 \mathrm{~kJ}^{-3} \mathrm{~m}^{-3}\right)$ when operating at plowing depth of $25 \mathrm{~cm}$ and plowing speed of $4.37 \mathrm{~km}$. $\mathrm{h}^{-1}$. These results attributed to the increasing the draft force requirements. This trend accords with Nassir (2017) and Kader (2008).

Table (11): Effect of interaction among moldboard type, plowing depth, and forward speed in specific energy.

\begin{tabular}{|c|c|c|c|c|c|}
\hline \multicolumn{6}{|c|}{ Forward speed $\left(\mathrm{km} \mathrm{h}^{-1}\right)$} \\
\hline & Depth & 4.37 & 5.51 & 6.76 & Means \\
\hline \multirow{4}{*}{ 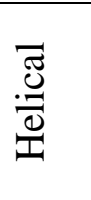 } & 15 & 170.94 & 165.33 & 162 & 166.09 \\
\hline & 20 & 135.3 & 176.1 & 184.29 & 165.23 \\
\hline & 25 & 114.3 & 142.74 & 164.4 & 140.48 \\
\hline & Means & 140.18 & 161.39 & 170.23 & 157.2667 \\
\hline \multirow{4}{*}{$\begin{array}{l}\frac{1}{0} \\
\bar{\pi} \\
0 \\
0 \\
0\end{array}$} & 15 & 181.86 & 175.62 & 175.8 & 177.76 \\
\hline & 20 & 146.7 & 192.99 & 190.86 & 176.85 \\
\hline & 25 & 143.19 & 160.11 & 154.83 & 152.71 \\
\hline & Means & 157.25 & 176.24 & 173.83 & 169.1067 \\
\hline \multirow{5}{*}{ 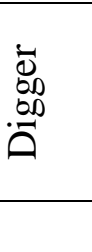 } & 15 & 210.99 & 205.77 & 196.50 & 204.42 \\
\hline & 20 & 163.80 & 171.12 & 200.08 & 178.33 \\
\hline & 25 & 188.82 & 177.00 & 146.31 & 170.71 \\
\hline & Means & 187.87 & 184.63 & 180.96 & 184.49 \\
\hline & L.S.D.(0.05) & \multicolumn{4}{|c|}{ Type*Depth* Speed $=7.03$} \\
\hline
\end{tabular}




\section{Soil pulverization efficiency (SPE)}

It can be noted from data of table (12) that there were significant $(\mathrm{p} \leq 0.05)$ differences among types of moldboard in terms of values of soil pulverization efficiency. The digger moldboard achieved the highest value of Soil pulverization efficiency (0.80) compared with general-purpose moldboard type which achieved the second highest value of soil pulverization efficiency was 0.74 , while the lowest value of soil pulverization efficiency achieved by helical moldboard (0.60). This because the soil pulverization efficiency mainly depended on pulverization index where increasing soil pulverization led to increasing soil pulverization efficiency. Similar results were reported by Aday (1997). The plowing depth had significant effect in soil pulverization efficiency (table 12). The results revealed reducing the soil pulverization efficiency from 0.74 to 0.70 when the plowing depth increasing from 15 to $20 \mathrm{~cm}$. However, increasing the plowing depth to $25 \mathrm{~cm}$ the soil pulverization efficiency recorded the second lowest value of 0.72 . This was due to that the shallow depth needing low energy to pulverization of soil and this made the equivalent energy close from the specific energy thereby increasing soil pulverization efficiency according the equation (7). These results agree with results reported by Aday et al. (2001) and Nassir (2017). Effect of forward speed on soil pulverization efficiency are shown in table (12). There is a trend that the soil pulverization efficiency increased with the increase in plowing speed from 4.37 to $7.03 \mathrm{~km} \mathrm{~h}^{-1}$ led to increase the soil pulverization efficiency from 0.59 to 0.80 . This could be attributed to decreasing the soil pulverization index related to the soil pulverization and this led to increasing in the equivalent energy which occurred when a higher plowing speed which played important rule in increasing the specific energy thereby the equivalent energy close from specific energy, consequently the soil pulverization efficiency increased according to equation (7). Similar results were reported by Nasser (2016).

Table (12): Effect of moldboard type, plowing depth, and forward speed in soil pulverization energy.

\begin{tabular}{cccc}
\hline Moldboard types & Helical & General-purpose & Digger \\
\hline & 0.60 & 0.74 & 0.80 \\
\hline Plowing depth & $15 \mathrm{~cm}$ & $20 \mathrm{~cm}$ & $25 \mathrm{~cm}$ \\
\hline & 0.74 & 0.70 & 0.72 \\
\hline Forward speed & $4.37 \mathrm{~km} . \mathrm{h}^{-1}$ & $5.51 \mathrm{~km} . \mathrm{h}^{-1}$ & $6.76 \mathrm{~km} . \mathrm{h}^{-1}$ \\
\hline & 0.59 & 0.75 & 0.80 \\
\hline L.S.D.(0.05) & Type $=0.002$ & Depth $=0.001$ & Speed $=0.003$ \\
\hline
\end{tabular}

The results of the interaction among type $\mathrm{x}$ depth $\mathrm{x}$ speed were shown in table (13). The interaction had effect significant in soil pulverization efficiency. The digger moldboard type recorded the highest value of soil pulverization efficiency was 0.91 when operating at plowing depth of $15 \mathrm{~cm}$ and plowing speed of $7.03 \mathrm{~km} \mathrm{~h}^{-1}$. While the helical moldboard type operating at plowing depth of 15 $\mathrm{cm}$ and low speed of $4.37 \mathrm{~km} \mathrm{~h}^{-1}$ recorded the lowest value of soil pulverization efficiency 
Alwan / Basrah J. Agric. Sci., 32(Spec. Issue 2): 373-388, 2019

.Table (13): Effect of interaction among moldboard type, plowing depth, and forward speed in soil pulverization energy.

\begin{tabular}{|c|c|c|c|c|c|}
\hline & \multicolumn{5}{|c|}{ Forward speed $\left(\mathrm{km} \mathrm{h}^{-1}\right)$} \\
\hline & Depth & 4.37 & 5.51 & 6.76 & Means \\
\hline \multirow{4}{*}{ 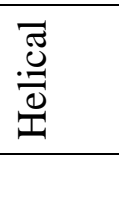 } & 15 & 0.40 & 0.70 & 0.78 & 0.63 \\
\hline & 20 & 0.45 & 0.70 & 0.45 & 0.53 \\
\hline & 25 & 0.49 & 0.68 & 0.78 & 0.65 \\
\hline & Means & 0.45 & 0.69 & 0.67 & 0.60 \\
\hline \multirow{4}{*}{ 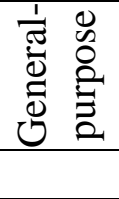 } & 15 & 0.58 & 0.77 & 0.89 & 0.75 \\
\hline & 20 & 0.69 & 0.73 & 0.86 & 0.76 \\
\hline & 25 & 0.61 & 0.72 & 0.83 & 0.72 \\
\hline & Means & 0.63 & 0.74 & 0.86 & 0.74 \\
\hline \multirow{4}{*}{ 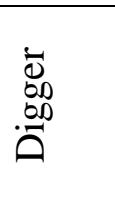 } & 15 & 0.77 & 0.84 & 0.91 & 0.84 \\
\hline & 20 & 0.65 & 0.81 & 0.88 & 0.78 \\
\hline & 25 & 0.69 & 0.80 & 0.84 & 0.78 \\
\hline & Means & 0.40 & 0.70 & 0.78 & 0.63 \\
\hline
\end{tabular}

(0.40). This trend accords with Aday \& AlEdan (2004) and Nassir (2016).

\section{Conclusions}

force compared to the general-purpose and helical moldboard types by the percentage of 12.13 and $19.49 \%$ respectively and the lowest value of soil pulverization index (high soil pulverization) by percentage 16.37 and $50.61 \%$ respectively. the DF and SPI increased significantly by $137.27 \%$ and $30.46 \%$ while the SE, the EQE, and SPE reduced by 18.19 , 17.80 and $2.70 \%$ respectively when increasing plowing depth from 15 to $25 \mathrm{~cm}$. Plowing speed had a significant effect on studied parameters when increasing plowing speed from 4.37 to $7.03 \mathrm{~km} \mathrm{~h}^{-1}$ the DF, SE, EQE, and SPE increased by 25.98, 45.11, 8.18 and $35.59 \%$ respectively, while the SPI decreased by $29.15 \%$. The best performance was for the digger moldboard at high plowing speed (7.03 $\left.\mathrm{km} . \mathrm{h}^{-1}\right)$ and low plowing depth $(15 \mathrm{~cm})$.
I like to thank the Department of Agricultural Machines and the Equipment, University of Basrah for their assist in conducting experiments and supplied the equipment and tool necessary for completing this study.

Conflict of interest: The authors declare that they have no conflict of interest.

\section{References}

Abdallah, F.E.; Ding, W.; Ding, Q. \& Pan, G. (2016). Design, development, and performance Evaluation of a trash-board moldboard plow for the interaction between soil and straw with two different water content levels. Agronomy, 6(2): 30-37.

Aday, S.H. (1997). Evaluation of the draught force and soil breaking up ability of a moldboard plough provided with pulverizer blades. Basrah J .Agric. Sci. 10(2): 31-47.

Aday, S.H. \& Al-Edan, A.A. (2004). Comparison between the field performance of a modified moldboard plow and a conventional moldboard plow in wet and friablke silty clay soils. B: The specific and 
equivalent energy efficiency Basrah. J. Agric. Sci., 17(1): 87-101.

Aday, Sh. H.; Hamid, K.A. \&. Salman, R.F (2001). The energy requirement and energy utilization efficiency of two plows type for pulverization of heavy soil. Iraqi J. Agric., 6(1): 137-146

Al- Hadithi, H.A. (2015). Effect of adding two vertical fins on moldboard plow knife in partitioning of soil slide and pulling force. Iraqi J. Agric. Sci., 44(5): 628-624. (In Arabic).

Al-Hashimy, L.A. (2012). The effect of disc tilt angle, tillage speed and depth on some of machinery unit technical and energy requirements parameters. Iraqi J. Agric. Sci., 43(2): 132-143.

Arvidsson, J.; Keller, T. \& Gustafsson K. (2004). Specific draft for moldboard plow, chisel plow and disk harrow at different water contents. Soil Tillage Res., 2(79): 221-231.

Black, C.A.; Evans, D.D.; White, J.L.; Ensminger J.E. \& Clark, F.E. (1993). Methods of soil analysis $6^{\text {th }} \mathrm{ed}$. Am. Soc. Agron. Madison, Wisconsin: 770pp.

Hillel, D. (1980). Application of soil physics. Academic press New York: 400pp.

Jasim, A.A. \&. Mankhi, M.A. (2012). Tractor speed tillage depth and performance power requirements and the pulling efficiency of the locally Modified plow. Iraqi J. Agric. Sci., 43(5): 122-126

Jacobs, C.O. \& Harrol W.R. (1983). Agricultural Power and Machinery. McGraw Hill Press, New York: 578pp.

Kader, A. (2008). Effect of some primary tillage implement on soil pulverization and specific energy. Misr. J. Ag. Eng., 25(3): 731-745.
Maky, E. \& Desir, F.L. (1984). Prediction and field measurement of tillage tool draft force and efficiency in cohesive soil. Tillage. Res. J., 4: 459-470.

Muhsin, S.J. (2017a). Performance study of moldboard plow with two types of disc harrows and their effect on some soil properties under different operating. Basrah J. Agric. Sci., 30(2): 1-15.

Muhsin, S.J. (2017b). Determination of energy requirements, plowed soil volume rate and soil pulverization ratio of chisel plow under various operating conditions. Basrah J. Agric. Sci., 30(1): 73-84.

Naderloo, L.; Alimadani, R.; Akram, A. Javadikia P. \&. Khanghah. H.Z. (2009). Tillage depth and forward speed effects on draft of three primary tillage implements in clay loam soil. J. Food Agric. Environ., 7: 382-385.

Nassir A.J. (2014). Requirements of pulverization energy of a tandem disc harrow at different pulverization depth and forward speed. Basrah J. Agric. Sci., 27(1): 301-315. (In Arabic).

Nassir, A.J. (2016). The Influence of Modify moldboard plow Shares in the pulverization energy under different forward speeds and plowing depths. Basrah J. Sci., 42(2): 5978. (In Arabic).

Nassir, A.J. (2017). The effect of tillage methods on energy pulverization requirements under various operating conditions in silty loamy soil. Thi-Qar J. Agric. Res., 6(2): 55-73.

Nassir, A.J. (2018). Effect of moldboard plow types on soil physical properties under different soil moisture content and tractor speed. Basrah J. Agric. Sci., 31(1): 48-58. 
Alwan / Basrah J. Agric. Sci., 32(Spec. Issue 2): 373-388, 2019

Nassir, A.J.; Meshaal, A.A \& Ramadhan, M.N. (2016). Effect of soil moisture content on pulverization energy of moldboard plow in silty loam soil. Basrah J. Agric. Sci., 29(2): 205-220. (In Arabic).

Rashidi, M. \& Keshavarzpour, F. (2007). Effect of different tillage methods on grain yield and yield components of Maize (Zea mays L.). Int. J. Agric. Biol., 9(2): 274-277.

Sahu, R.K. \& Raheman, H. (2006). Draught prediction of agricultural implements using reference tillage tools in sandy clay loam soil. Biosyst. Eng., 94: 275-284.

Taniguchi, T.; Makanga, J.T.; Ohtomo, K.\& Kishimoto, T. (1999). Draft and soil manipulation by a moldboard plow under different forward speed and body attachments. Trans. Am. Soc. Agric. Biol. Eng., 42: 1517-1521. 